\title{
Seasonal analysis of bacteriological quality of drinking water sources in communities surrounding Lake Bosomtwe in the Ashanti Region of Ghana
}

\author{
M. O. Akrong ${ }^{1}$ - F. K. Amu-Mensah ${ }^{1}$ - M. A. Amu-Mensah ${ }^{1}$ - H. Darko ${ }^{1}$ - G. N. D. Addico ${ }^{1}$. J. A. Ampofo ${ }^{1}$
}

Received: 2 November 2017 / Accepted: 16 April 2019 / Published online: 3 May 2019

(c) The Author(s) 2019

\begin{abstract}
The 26 communities surrounding the rim of the largest Crater Lake in Africa, the Lake Bosomtwe, depend on the lake for livelihood support. Water sources such as lake, streams and boreholes used as drinking water sources were collected quarterly for a period of 2 years. These were analysed bacteriologically for the determination of total and faecal coliform, Escherichia coli, Aeromonas sp., Enterococcus sp., Salmonella sp., Pseudomonas sp. and total heterotrophic bacteria (THB) using membrane filtration and pour plate techniques. The seasonal variations of these bacteria in the water sources were determined. The results showed variation of bacteria counts in all the water sources. The highest $E$. coli counts of $2.9 \times 10^{3} \mathrm{cfu} / 100 \mathrm{ml}$ were recorded in the lake and the least in the borehole $2.1 \times 10^{1} \mathrm{cfu} / 100 \mathrm{ml}$. The difference between the total coliform, faecal coliform and E. coli counts and the water sources was significant $(p<0.05)$. All the bacteria count with the exception of THB, in the different water sources, had higher bacteria counts during the dry season than the wet season which are statistically significant $(p<0.05)$. The bacteria contamination of these water sources renders them bacteriologically not suitable for drinking purposes; therefore, drinking these waters without any form of treatments could pose health risk to consumers. These water sources can, however, be used for domestic purposes.
\end{abstract}

Keywords Lake Bosomtwe $\cdot$ Water quality $\cdot$ Seasonal changes $\cdot$ Bacterial load $\cdot$ Anthropogenic activities $\cdot$ E. coli

\section{Introduction}

Water is essential for life and the well-being of all people as well as an important natural resource useful for domestic and developmental purposes. The quality of the water sources greatly impacts on the health status of the consumers. Natural water systems such as lakes provide fisheries, flood plains, agriculture, natural services and products like aquifer replenishment, water quality improvement and biodiversity (Naiman 1992; Edmondson 1991). Lakes support transportation, recreation and other cultural amenities (WLVARC 2007).

Untreated surface and underground water are still commonly used for domestic purposes in many areas in developing countries (World Health Report 2002), and the communities surrounding the rim of Lake Bosomtwe are not

M. O. Akrong

markosaakrong@gmail.com

1 CSIR, Water Research Institute, Accra, Ghana exception. Sources of water flowing into the lake include direct rainfall, streams, surface runoff and seepage from the hill slopes. Some communities surrounding the lake use it as a tourist centre and for recreational purpose. Most of riparian communities depend on the lake, streams and boreholes as their drinking water source (Amu-Mensah et al. 2014). Although these water sources serve a great benefit to the communities, they are usually under threat as a result of anthropogenic activities in some of the communities surrounding the lake and the streams (Amu-Mensah et al. 2014). Furthermore, sources of contamination in the water resource may involve seepage from broken septic tanks, pit latrines and runoff water containing faecal matter, fertiliser, pesticide and fungicide from farm lands (Geldreich 2005; Hart and Zabbey 2005). According to Hunter (1997) and Pruss et al. (2002), water-borne diseases may account for one-third of the intestinal infections worldwide, while it is estimated that water, sanitation and hygiene are responsible for $40 \%$ of all deaths and $5.7 \%$ of the total disease burden occurring worldwide. Unsafe water is a global public health threat, placing persons at risk for a host of diarrhoeal and 


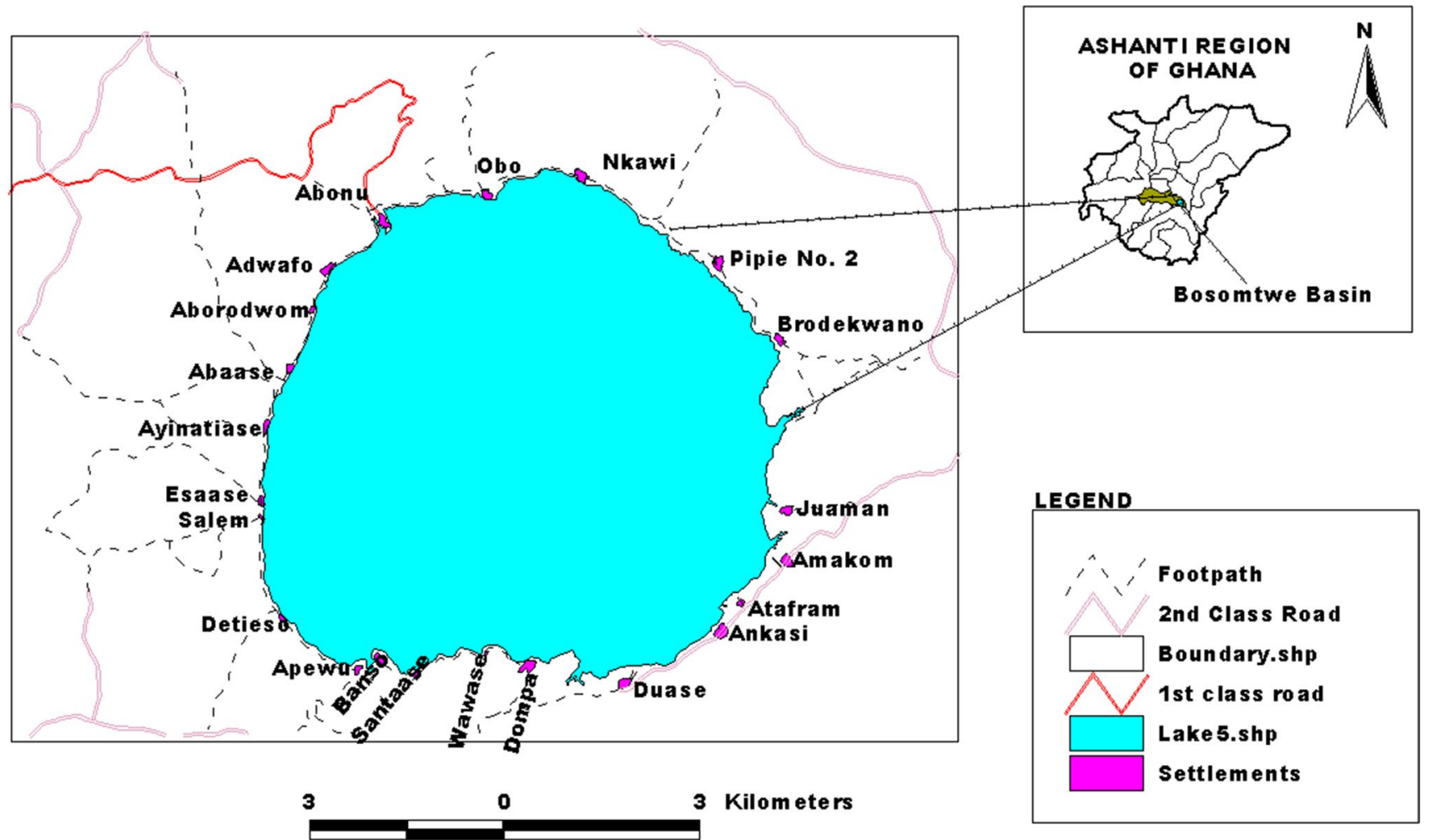

Fig. 1 Map of study area

other diseases as well as chemical intoxication (Hughes and Koplan 2005). Bacteria of interest which play a major role in water quality include Escherichia coli (E. coli), Salmonella sp. and Vibrio cholera (Birmingham et al. 1997). These bacteria cause disease such as typhoid fever, diarrhoea, dysentery, gastroenteritis and cholera. In order to ensure and maintain good health, water should be of good quality meeting local and WHO recommended standards (Cheesbrough 2000).

The aim of this study was to determine the bacteriological quality of the water sources (lake, stream and boreholes) used by communities surrounding the Lake Bosomtwe in the Bosomtwe and Bosome Freho Districts in the Ashanti Region of Ghana and to establish if seasonal changes in climate affect these quality issues.

\section{Materials and methods}

\section{Study area}

This research was carried out within the Lake Bosomtwe and surrounding communities. There are about 26 communities surrounding the rim of the Crater Lake who depend on it for livelihood support. Lake Bosomtwe is located in the Ashanti Region of Ghana within latitudes $6^{\circ} 28^{\prime} 15.11^{\prime \prime} \mathrm{N}$ and $6^{\circ} 32^{\prime} 28.53^{\prime \prime} \mathrm{N}$ and longitudes $1^{\circ} 24^{\prime} 24.06^{\prime \prime} \mathrm{W}$ and $1^{\circ} 26^{\prime} 46.30^{\prime \prime} \mathrm{W}$ (Fig. 1). It is the only closed lake in Ghana and Africa, and the third largest closed lake in the world. The lake is enclosed within two administrative districts, Bosomtwe District and the newly created Bosome Freho District. The elevation of the lake surface is currently at $97 \mathrm{~m}$ above MSL (assumed to be $0.0 \mathrm{~m}$ ). The months of March to November are relatively humid with rainfall satisfying evapotranspiration rates from a minimum of $71 \%$ to a maximum of $197 \%$. A significant amount of rainwater runoff over the land occurs in these months. Monthly mean temperatures range from $30{ }^{\circ} \mathrm{C}$ in March to about $24{ }^{\circ} \mathrm{C}$ in August, and relative humidity varies from 90 to $95 \%$ in the rainy season, to 75 to $80 \%$ in the dry season. Rainfall deficits occur in the region because of the high evapotranspiration rates that occur in November to March.

\section{Sample collection}

A total of 222 water samples were collected from three water sources. These sources were: 126 lake samples from 24 surrounding communities (Abono, Krobo, Jbo Nsebi, Brodekwano, Nkwawi, Esisriwa Dadeimu, Mmbemu, Pepie, Abrodwom, Konkonba Dadeimu, Agyamanmu, Amakom, Adwafo, Abease, Rainbow, Esaase, Apewu, Dompa, Duase, Detieso, middle of lake and Ankaase), 80 borehole samples from 
randomly selected 16 communities (Detieso, Dompa, Agyamanmu, Duase, Amakom, Apewu, Adwafo, Brodekwano, Pipie, Jbu Nsebi, Abono, Abease, Abrodwom, Ankaase, Esaase and Nkwawie) and 16 stream samples from three communities (Abono bo stream (upstream and downstream) at Abono, Nana Abrewa stream at Apewu and Atafram stream at Ankaase). Sampling was conducted from 2012 to 2014. The collection spans from dry to wet seasons. All samples were aseptically collected in well-labelled 500-ml sterilised bottles and were transported at $4{ }^{\circ} \mathrm{C}$ (in a cool box with ice) to the CSIR-Water Research Institute Microbiology Laboratory for bacteria examination. All water samples were analysed within $24 \mathrm{~h}$ of collection.

\section{Bacteriological analysis}

All analyses were carried out aseptically, and this followed the standard methods as described in APHA (2012).

The bacteriological analysis of the water samples from the lake and streams was performed for the presence of coliform bacteria, total and faecal coliform, E. coli, Aeromonas sp, Enterococcus sp. (these bacteria can survive longer in adverse environmental conditions due to their bacterial membrane and can cause Enterococcal infections that include urinary tract infections, hepatobiliary sepsis, endocarditis, surgical wound infection, bacteraemia and neonatal sepsis), Salmonella sp., Pseudomonas sp. (these are opportunistic pathogen found in moist environments such as soil, water as well as on vegetation and can cause urinary tract infections in immunocompromised individuals) and total heterotrophic bacteria (THB).

Total coliform, faecal coliform, E. coli and total heterotrophic bacteria tests were conducted on the borehole samples. Membrane filtration and pour plate techniques were employed in analysing the water samples. Aliquots of $100 \mathrm{ml}$ each of water samples were separately filtered through $0.45-\mu \mathrm{m}$-pore-size membrane filters. Determination of total coliform, E. coli and faecal coliform was undertaken by placing the filter on Hicrome (Difco) Media in Petri dishes and incubated at $37 \pm 0.5^{\circ} \mathrm{C}$ and $44^{\circ} \mathrm{C}$ for $16-24 \mathrm{~h}$, respectively. Salmonella sp., Pseudomonas sp. and Aeromonas sp. were determined by placing the filter on SS agar, Cetrimide and Aeromonas media, respectively, in Petri dishes and incubating at $37 \pm 0.5{ }^{\circ} \mathrm{C}$, for $16-24 \mathrm{~h}$. Slanetz and Bartley medium was used for the determination of Enterococcus spp. and was incubated at $44{ }^{\circ} \mathrm{C} \pm 0.5{ }^{\circ} \mathrm{C}$ for $48 \mathrm{~h}$. Total heterotrophic bacteria were determined by the pour plate technique using aliquot of $1 \mathrm{ml}$ of water sample on nutrient agar and incubating at $37 \pm 0.5{ }^{\circ} \mathrm{C}$ for $48 \mathrm{~h}$. Colonies were counted with the aid of colony counter, and numbers were expressed as coliform forming unit (cfu) per $100 \mathrm{ml}$ for membrane filtration and cfu per $1 \mathrm{ml}$ for pour plate technique (APHA 2012).

\section{Statistical analysis}

Data obtained were subjected to statistical analysis using SPSS statistical package version 20. Geometric means of bacterial counts were computed and presented in table. Analysis of variance (ANOVA) and non-parametric test (i.e. Kruskal-Wallis test) were used to determine differences in bacterial count from various sampling points at $95 \%$ level of significance.

\section{Results and discussion}

All the water sources contained bacteria in various counts. Table 1 shows the range and mean values of total coliform, faecal coliform, E. coli, Aeromonas spp., Enterococcus spp., Salmonella spp., Pseudomonas spp. and total heterotrophic bacteria counts of lake, stream and borehole water samples over the study period. The presence of faecal coliform bacteria and $E$. coli in water gives an indication of faecal contamination by warm-blooded animals (Latha and Mohan 2013). Their occurrence may indicate the presence of other pathogens responsible for infectious diseases such as cholera, gastroenteritis, dysentery and typhoid fever after ingestion of contaminated water. Aeromonas spp. were recorded in the lake throughout the study period. These bacteria are found in lakes, rivers, marine waters, sewage effluents and drinking waters and are known potential agent of gastroenteritis, septicaemia, meningitis, respiratory as well as urinary tract infections particularly in immunocompromised individuals and children $<5$ years. Also, contact with Aeromonas spp. contaminated water can cause skin inflammations such as cellulites, ulcers, eczema and mionecrosis (Krovacek et al. 1992; Legnani et al. 1998). The mean highest total coliform counts were recorded in the stream samples $\left(2.6 \times 10^{3} \mathrm{cfu} / 100 \mathrm{ml}\right)$, while the least count occurred in the borehole samples $\left(3.2 \times 10^{2} \mathrm{cfu} / 100 \mathrm{ml}\right)$. The $E$. coli count for the lake samples ranged from $<1$ to $5.4 \times 10^{3} \mathrm{cfu} / 100 \mathrm{ml}$ with a mean value of $2.9 \times 10^{3} \mathrm{cfu} / 100 \mathrm{ml}$, while in the borehole samples, it ranged from $<1$ to $6 \times 10^{1} \mathrm{cfu} / 100 \mathrm{ml}$ with a mean value of $2.1 \times 10^{1} \mathrm{cfu} / 100 \mathrm{ml}$. Also, $44 \%$ of the sampling sites had counts within the acceptable limit of $0 \mathrm{cfu} / 100 \mathrm{ml}$ for drinking purpose. Stream samples ranged from $2 \times 10^{3}$ to $4.2 \times 10^{3} \mathrm{cfu} / 100 \mathrm{ml}$ with a mean value of $1.1 \times 10^{3} \mathrm{cfu} / 100 \mathrm{ml}$. The highest bacteria count in all the water sources was recorded in the stream samples followed by the lake and then borehole, which recorded the least counts. The high bacteria counts recorded in the lake could be attributed to the rapid increase in population and

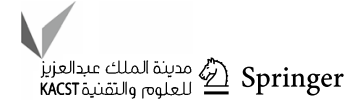


Table 1 Bacteria counts in the three water sources

\begin{tabular}{|c|c|c|c|c|}
\hline \multirow[t]{2}{*}{ Bacteria type (units of measure) } & \multirow[t]{2}{*}{ Statistic } & \multicolumn{3}{|c|}{ Bacterial count in source of water } \\
\hline & & Lake & Borehole & Stream \\
\hline \multirow[t]{3}{*}{ Total coliform $(\mathrm{cfu} / 100 \mathrm{ml})$} & Mean & $2.3 \times 10^{3}$ & $3.2 \times 10^{2}$ & $2.6 \times 10^{3}$ \\
\hline & Minimum & $<1$ & $<1$ & $1.7 \times 10^{2}$ \\
\hline & Maximum & $9.3 \times 10^{3}$ & $2.3 \times 10^{3}$ & $6.5 \times 10^{3}$ \\
\hline \multirow[t]{3}{*}{ Faecal coliform $(\mathrm{cfu} / 100 \mathrm{ml})$} & Mean & $6.0 \times 10^{2}$ & $2.1 \times 10^{1}$ & $1.1 \times 10^{3}$ \\
\hline & Minimum & $<1$ & $<1$ & $2.0 \times 10^{0}$ \\
\hline & Maximum & $4.2 \times 10^{3}$ & $1.9 \times 10^{2}$ & $4.2 \times 10^{3}$ \\
\hline \multirow[t]{3}{*}{ E. $\operatorname{coli}(\mathrm{cfu} / 100 \mathrm{ml})$} & Mean & $2.9 \times 10^{2}$ & $1.8 \times 10^{0}$ & $3.2 \times 10^{2}$ \\
\hline & Minimum & $<1$ & $<1$ & $2.0 \times 10^{0}$ \\
\hline & Maximum & $3.3 \times 10^{3}$ & $6.0 \times 10^{1}$ & $1.4 \times 10^{3}$ \\
\hline \multirow[t]{3}{*}{ Aeromonas sp. (cfu/100 ml) } & Mean & $1.4 \times 10^{1}$ & - & $5.0 \times 10^{1}$ \\
\hline & Minimum & $<1$ & & $<1$ \\
\hline & Maximum & $3.7 \times 10^{2}$ & & $5.6 \times 10^{2}$ \\
\hline \multirow[t]{3}{*}{ Pseudomonas sp. (cfu/100 ml) } & Mean & $2.0 \times 10^{3}$ & - & $2.4 \times 10^{3}$ \\
\hline & Minimum & $<1$ & & $3.8 \times 10^{1}$ \\
\hline & Maximum & $1.0 \times 10^{4}$ & & $8.4 \times 10^{3}$ \\
\hline \multirow[t]{3}{*}{ Salmonella sp. (cfu/100 ml) } & Mean & $9.8 \times 10^{2}$ & - & $1.2 \times 10^{3}$ \\
\hline & Minimum & $<1$ & & $<1$ \\
\hline & Maximum & $8.4 \times 10^{3}$ & & $9.8 \times 10^{3}$ \\
\hline \multirow[t]{3}{*}{ Enterococcus sp. (cfu/100 ml) } & Mean & $9.2 \times 10^{2}$ & - & $1.9 \times 10^{3}$ \\
\hline & Minimum & $<1$ & & $8.0 \times 10^{0}$ \\
\hline & Maximum & $5.6 \times 10^{3}$ & & $5.6 \times 10^{3}$ \\
\hline \multirow[t]{3}{*}{ Total heterotrophic bacteria (cfu/1 ml) } & Mean & $2.0 \times 10^{3}$ & $2.7 \times 10^{3}$ & $1.7 \times 10^{3}$ \\
\hline & Minimum & $1.1 \times 10^{1}$ & $1.0 \times 10^{0}$ & $1.4 \times 10^{2}$ \\
\hline & Maximum & $6.3 \times 10^{3}$ & $7.0 \times 10^{3}$ & $3.7 \times 10^{3}$ \\
\hline
\end{tabular}

Means computed are geometric means developmental projects such as construction of hotels, tourist lodges and other tourist facilities around the lake, in the last decade, coupled with discharge of untreated waste from these facilities. These and other anthropogenic activities such as swimming by both humans and animals, washing of clothes and domestic utensils and rearing of animals close to the lake as indicated by Latha and Mohan (2013) in their study in India could contribute to the contamination. The mean total heterotrophic bacteria (THB) counts of all the water sources were generally above the Ghana Standard limit of $500 \mathrm{cfu} / 1 \mathrm{ml}$ accepted for drinking water. Mean values of THB count recorded in the water samples were $2.0 \times 10^{3} \mathrm{cfu} / \mathrm{ml}, 2.7 \times 10^{3} \mathrm{cfu} / \mathrm{ml}$ and $1.7 \times 10^{3} \mathrm{cfu} /$ $\mathrm{ml}$ in lake, borehole and stream, respectively. The high bacteria counts in the lake samples could be attributed to its large surface and its function as a sink, collecting pollutants and therefore exposing it to contamination through runoffs, anthropogenic activities such as swimming, washing of clothes, fishing net and cooking utensils (Amu-Mensah et al. 2014). The concentration of piggeries, free-range chickens and dogs may also account for the high bacteria count in the lake. Furthermore, direct discharge of untreated wastewater from some guest houses and resorts centres along the fringes of the lake could contribute to the bacteria contamination (Amu-Mensah et al. 2014). In effect, consumers of this contaminated water sources are prone to water-borne diseases such as diarrhoea, cholera, etc.

The bacteriological quality of the borehole was relatively far better than the lake and the stream. In general, significant differences were observed in the total coliform, faecal coliform and E. coli counts between the water sources, especially between the borehole and the other two water sources. The difference in the faecal coliform counts between the three water sources was statistically significant $(p<0.05)$, while the difference in total coliform and E. coli counts between the lake and stream was not significant $(p>0.05)$. This could be attributed to the exposure of the streams and the lakes to pollution from runoff and other anthropogenic activities.

The mean counts of each bacteria (E. coli, total coliform, faecal coliform and THB) recorded in the water samples irrespective of its source were above the Ghana Standard Authority (GSA) recommended level and WHO guideline for drinking water of $0 \mathrm{cfu} / 100 \mathrm{ml}$ for all the bacteria 


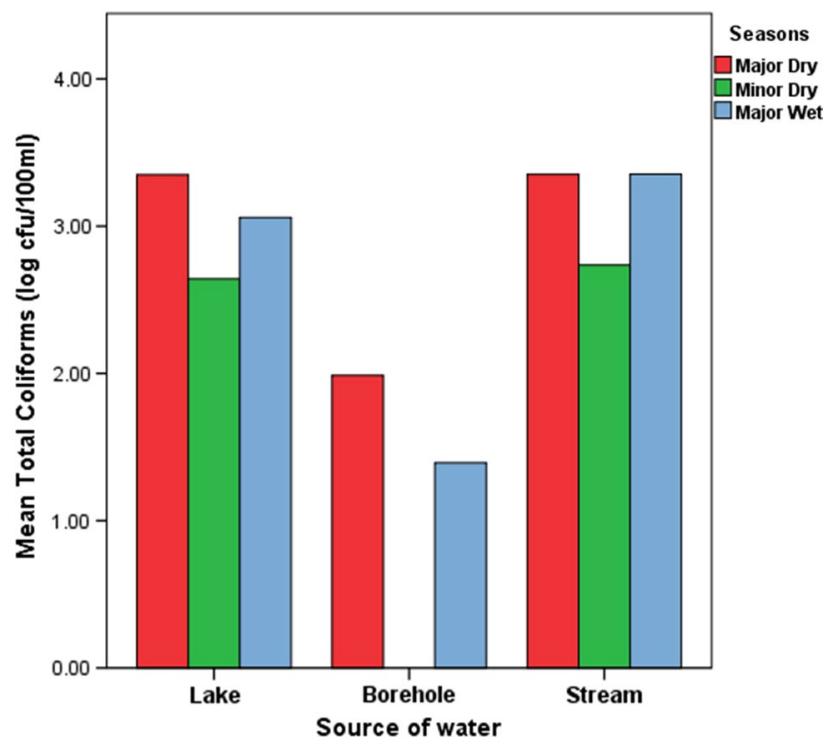

Fig. 2 Seasonal variations of TC in water

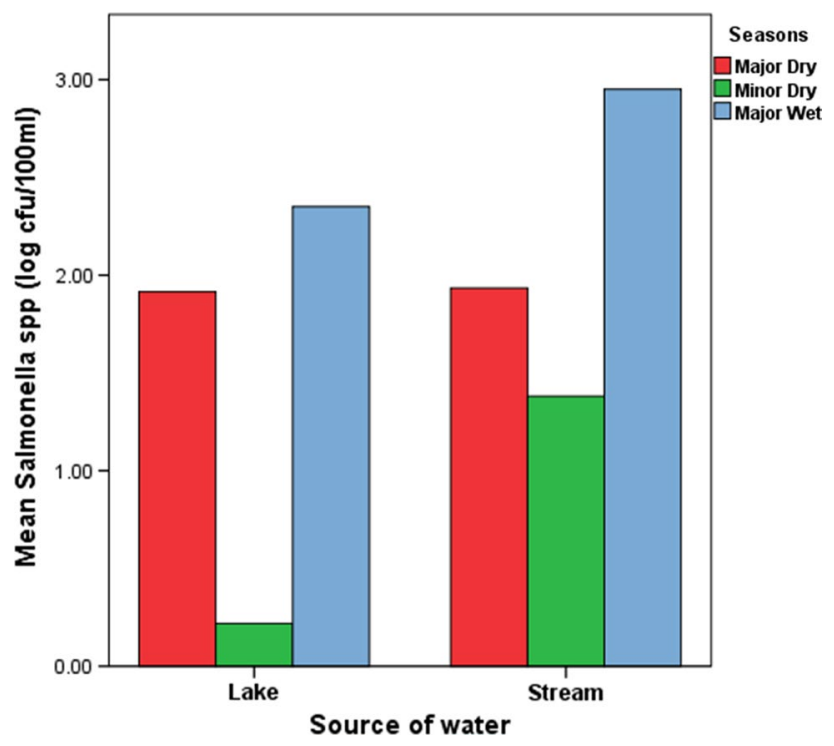

Fig. 3 Seasonal variations of Salmonella sp. in water

analysed and $<500 \mathrm{cfu} / \mathrm{ml}(2.69 \mathrm{log} \mathrm{cfu} / 1 \mathrm{ml})$ for THB according to the Ghana Standards Authority (Figs. 2, 3).

Seasonal variation of the bacteria counts was observed in the water sources. High and significant bacteria counts of total coliform $(p=0.035)$, E. coli $(p=0.017)$ and faecal coliform ( $p=0.003$ ) were recorded during the dry season (Fig. 4). The environmental conditions coupled with the presence of stagnant water around some of the boreholes could contribute to these counts as the condition favours bacteria growth. This result is in agreement with studies conducted by Odonkor and Addo (2013) on borehole sources in

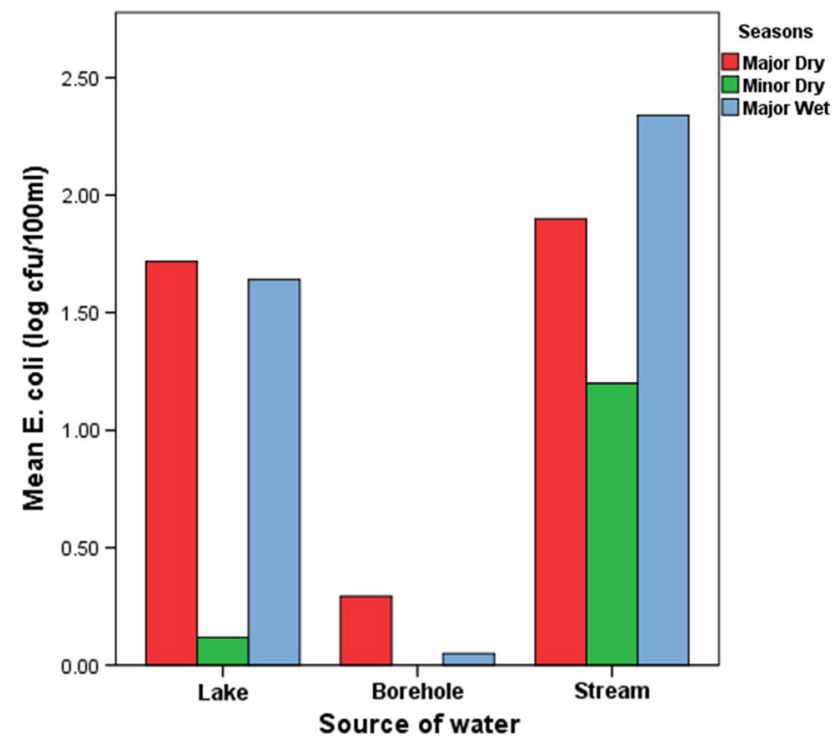

Fig. 4 Seasonal variations of $E$. coli in water sources

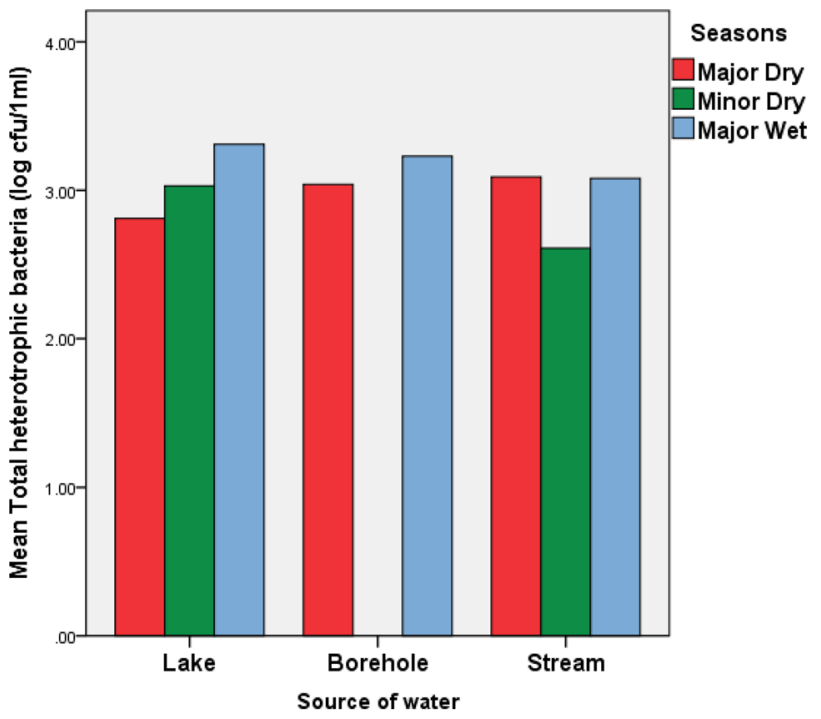

Fig. 5 Seasonal variations of THB in water sources

rural Ghanaian communities. However, high and significant $(p=0.008)$ total heterotrophic bacteria counts were recorded during the wet season. This corroborate finding by Obafemi et al. (2018) (Fig. 5).

On the contrary, higher bacteria counts with the exception of Enterococcus sp. and THB were recorded during the wet season in the stream samples than the major dry and minor dry seasons. These differences were, however, significant for only faecal coliform $(p=0.031)$ and Salmonella sp. $(p=0.040)$.

With the exception of $E$. coli and faecal coliform which showed a significant difference between the various sampling 
points around the lake, all the bacterial counts did not show any significant difference of bacteria counts between the various sampling points. This in effect indicates a uniform distribution of bacteria in the lake. Generally, there were significant differences in the bacteria counts in the lake samples between the three seasons (major dry, minor dry and major wet). This difference was between the minor dry and major wet as well as minor dry and major dry (Figs. 2, 3).

Although, there could be the presence of other pathogens such as viruses, protozoa or helminths eggs in the water sources which can pose health risk to consumers, these pathogens were not considered in this study because of logistics.

\section{Conclusion}

From the study, the water sources used by the communities around the Bosomtwe lake are contaminated with bacteria and are bacteriologically unsafe to be used as a drinking water source without any form of treatment such as boiling and chlorination, especially with the borehole source. The borehole source was, however, of a relatively good quality than the other two sources. Generally, high bacteria counts were recorded in the lake and stream water sources during the wet season largely as a result of pollution from runoff.

Open Access This article is distributed under the terms of the Creative Commons Attribution 4.0 International License (http://creativeco mmons.org/licenses/by/4.0/), which permits unrestricted use, distribution, and reproduction in any medium, provided you give appropriate credit to the original author(s) and the source, provide a link to the Creative Commons license, and indicate if changes were made.

\section{References}

Amu-Mensah F, Akrong M, Amu-Mensah M, Darko H (2014) Sustainable management of Lake Bosomtwe in the Ashanti Region of Ghana; Hydrology, water quality and anthropology factors. Final report for UNESCO, Accra Office, p. 151, Technical report CSIR-WRI

APHA, AWWA, WEF (2012) Standard methods for examination of water and wastewater, 22nd edn. American Public Health Association, Washington. ISBN: 978-087553-013-0

Birmingham ME, Lea LA, Ndayiminje N, Nkurikiye S, Harsh BS, Well JG, Ijeming MS (1997) Epidemic cholera in Burnndi, patterns of transmission in the Gadat Rift Valley Lake Region. Lancet 349:981-982

Cheesbrough M (2000) District laboratory practice for tropical countries, part 2. Cambridge University Press, Cambridge, pp 143-154

Edmondson WT (1991) The uses of ecology: Lake Washington and Beyond. University of Washington Press, Seattle

Geldreich EE (2005) The bacteriology of water. In: Coller L, Balows A, Sussman M (eds) Topley and Wilson's microbiology and microbial infections, 9th edn. Arnold, London, pp 351-363

Hart AI, Zabbey N (2005) Physicochemical and benthic fauna of Woji Creek in the Lower Niger Delta, Nigeria. Environ Ecol 23(2):361-368

Hughes JM, Koplan JP (2005) Saving lives through global safe water. J Emerg Infect Dis 11(10):1636-1637

Hunter PR (1997) Waterborne diseases epidemiology and ecology, 1st edn. Wiley, Chichester. ISBN: 0471-96646-0

Krovacek K, Faris A, Baloda SB, Lindberg T, Peterz M, Mansson I (1992) Isolation and virulence profiles of Aeromonas spp. from different municipal drinking water supplies in Sweden. Food Microbiol 9:215-222

Latha N, Mohan MR (2013) Microbial pollution-total coliform and fecal coliform of Kengeri lake, Bangalore region Karnataka, India. Int J Sci Res Publ 3(11):1-3

Legnani P, Leoni E, Soppelsa F (1998) The occurence of Aeromonas spp. in drinking water supplies of the Dolomite Mountains. J Appl Microbiol 85:271-278

Naiman RJ (1992) Watershed management—balancing sustainability and environmental change. Springer, New York

Obafemi OO, Adebolu AE, Abosede OM (2018) Bacteriological assessment of boreholes and wells water in Akungba-Akoko. Nigeria. Int J Agric Environ Biores 3(6):80-87

Odonkor ST, Addo KK (2013) Bacteriological profile and physicochemical quality of ground water: a case study of bore hole water sources in a rural Ghanaian community. Int J Curr Microbiol Appl Sci 2(8):21-40

Pruss A, Kay D, Fewtrell L, Bartrem J (2002) Estimating the burden of disease due to water, sanitation and hygiene at the global level. Environ Health Perspect 110:537-542

World Health Report (2002) Reducing risks, promoting healthy life. World Health Organization, Geneva

World Lake Vision Action Report Committee (WLVARC) (2007) World lake vision action report: implementing the world lake vision for the sustainable use of lakes and rivers. International Lake Environment Committee, Kusatsu City, Shiga, Japan. www. who.int/water_sanitation_health/dwq/GDW11rev1and2

Publisher's Note Springer Nature remains neutral with regard to jurisdictional claims in published maps and institutional affiliations. 